\title{
Prevalence of Human Parainfluenza Viruses and Noroviruses Genomes on Office Fomites
}

\author{
Agata Stobnicka ${ }^{1} \cdot$ Małgorzata Gołofit-Szymczak ${ }^{1} \cdot$ Angelina Wójcik-Fatla $^{2} \cdot$ Violetta Zając $^{2}$. \\ Joanna Korczyńska-Smolec ${ }^{3} \cdot$ Rafał L. Górny $^{1}$
}

Received: 14 June 2017 / Accepted: 22 November 2017 / Published online: 1 December 2017

(c) The Author(s) 2017. This article is an open access publication

\begin{abstract}
The aim of this study was to evaluate the potential role of office fomites in respiratory (human parainfluenza virus 1-HPIV1, human parainfluenza virus 3-HPIV3) and enteric (norovirus GI-NoV GI, norovirus GII-NoV GII) viruses transmission by assessing the occurrence of these viruses on surfaces in office buildings. Between 2016 and 2017, a total of 130 surfaces from open-space and non-open-space rooms in office buildings located in one city were evaluated for HPIV1, HPIV3, NoV GI, and NoV GII viral RNA presence. Detection of viruses was performed by RT-qPCR method. Study revealed 27 positive samples, among them 59.3\% were HPIV3-positive, 25.9\% HPIV1-positive, and 14.8\% NoV GII-positive. All tested surfaces were NoV GI-negative. Statistical analysis of obtained data showed that the surfaces of office equipment including computer keyboards and mice, telephones, and desktops were significantly more contaminated with respiratory viruses than the surfaces of building equipment elements such as door handles, light switches, or ventilation tracts $\left(\chi^{2} p=0.006\right.$; Fisher's Exact $p=0.004)$. All examined surfaces were significantly more contaminated with HPIVs than NoVs $\left(\chi^{2} p=0.002\right.$; Fisher's Exact $p=0.003)$. Office fomites in open-space rooms were more often contaminated with HPIVs than with NoVs $\left(\chi^{2} p=0.016\right.$; Fisher's Exact $p=0.013)$. The highest average concentration of HPIVs RNA copies was observed on telephones $\left(1.66 \times 10^{2}\right.$ copies $\left./ 100 \mathrm{~cm}^{2}\right)$, while NoVs on the light switches $\left(1.40 \times 10^{2}\right.$ copies $\left./ 100 \mathrm{~cm}^{2}\right)$. However, the Kruskal-Wallis test did not show statistically significant differences in concentration levels of viral RNA copies on surfaces between the all tested samples. This study unequivocally showed that individuals in office environment may have contact with both respiratory and enteric viral particles present on frequently touched surfaces.
\end{abstract}

Keywords Parainfluenza $\cdot$ Norovirus $\cdot$ Office fomites $\cdot$ RT-qPCR

\section{Introduction}

According to World Health Organization, there are about 1.7 million deaths from diarrheal infections and about 1.5 million deaths from respiratory infections worldwide every year (Pruss-Ustun and Covalan 2006). As estimated, 60\% of human diseases are induced by viral agents, and among

Agata Stobnicka

agsto@ ciop.pl

1 Central Institute for Labour Protection - National Research Institute, Czerniakowska 16 Street, 00-701 Warsaw, Poland

2 Department of Health Biohazards and Parasitology, Institute of Rural Health, Jaczewskiego 2 Street, 20-090 Lublin, Poland

3 Independent Public Healthcare Center, Wadowicka 3 Street, 34-122 Wieprz, Poland them the most common illnesses are caused by respiratory and enteric viruses (Barker et al. 2001; McElhaney 2003).

From the medical point of view, human parainfluenza viruses (HPIVs), belonging to Paramyxoviridae family, are very important respiratory pathogens. There are four recognized serotypes of HPIVs: HPIV1, HPIV2, HPIV3, and HPIV4. HPIV1 and HPIV3 are the major causes of lower respiratory infections in children, the immunocompromised and chronically ill adults as well as among elderly (Collins et al. 1996; Falsey et al. 1995; Glezen et al. 1984, 2000; Liu et al. 2013; Whimbey et al. 1997). Infections in adults are usually less severe; however, serious infections caused by HPIVs among elderly and individuals with immunodeficiencies have been reported (Glasgow et al. 1995; Hendley 1990; Jarvis et al. 1979; Wendt et al. 1992). Symptoms of HPIV infections include cough, pharyngeal discomfort, nasal obstruction, coryza, sneeze, dyspnea, hoarseness, 
fever, chills, dizziness, headache, myalgia, and debilitation. Pathogenic activity of HPIVs in gastrointestinal illnesses is also suggested (Liu et al. 2013). According to Liu et al. (2013), HPIV1 and HPIV3 occurrences show seasonal trend with peak concentration on autumn turned to winter (September-November).

Noroviruses (Norwalk, NoV), belonging to Caliciviridae family, are the most common cause of epidemic gastroenteritis, responsible for at least $50 \%$ of all gastroenteritis outbreaks worldwide (Hall et al. 2011, 2013). Noroviruses have been divided into six established genogroups (GIGVI) (Green 2013); however, provisional genogroup VII is also proposed (Vinjé 2015). NoV GII has emerged as the predominant NoV genotype in outbreaks of gastroenteritis worldwide (Huhti et al. 2011). Noroviruses are the most common pathogens associated with gastroenteritis in all age groups (Koopmans and Duizer 2004), however the most severe disease occurs in young children, among elderly, and persons with chronic illness (Estes et al. 2006). The infection is usually manifested by vomiting, diarrhea, nausea, fever, abdominal pain, headache, myalgia, general malaise, and chills. Norovirus-associated illnesses appeared to have winter-spring seasonality (January-March) (Arias et al. 2009; Marshall et al. 2005).

Viruses are probably the most common cause of infectious diseases, which are acquired indoors (Aitken and Jefferies 2001; Barker et al. 2001). Crowded indoor environments, like business office buildings, represent greater risk for dissemination of viral infections (La Rosa et al. 2013). The efficiency of transmission of viruses from hands to surfaces of often-touched objects depends on various factors such as species of the virus, the frequency and accuracy of hand-washing, and the physicochemical properties of specific surface (Julian et al. 2010). Available data suggest that viruses present on hands may contaminate the surface of 5-14 subsequently touched objects (Barker et al. 2004; von Rheinbaben et al. 2000). Viral contamination of one or two of the most touched surfaces in the office may result in the spread of viruses to $40-60 \%$ of the remaining surfaces within 2-4 h (Gerba 2014). At the room temperature, on non-porous surfaces, viruses keep their stability and infectious capacity (depending on environmental conditions) from $2 \mathrm{~h}$ to 1 week for HPIVs and from 3 to 4 weeks for NoVs, which suggest their important role in dissemination of infections among occupants (Doultree et al. 1999; Hendrickson 2003).

There are some evidences that contaminated surfaces may play a key role in the spreading of viral diseases (Boone and Gerba, 2007; Cheesbrough et al. 2000; Tuladhar et al. 2012), but knowledge concerning the role of specific surfaces and everyday-use-objects in viral transmission is still scarce. Infection control requires a clear understanding of viral transmission through everyday-use objects (Goldman 2000).
Hence, the aim of this study was to evaluate the prevalence of parainfluenza viruses (HPIV1, HPIV3) and noroviruses (NoV GI, NoV GII) on frequently touched surfaces in office buildings during season conducive to respiratory and enteric infections.

\section{Materials and Methods}

\section{Samples}

Swabs from selected fomites were collected in office buildings located in Warsaw (Poland). A total of 130 samples, 65 from open-space (OS; $\geq 5$ occupants) and 65 from nonopen-space (NOS; $<5$ occupants) office rooms, were evaluated over 9-month period (September 2016-May 2017). Samples were collected during regular work hours. Occupants were asked to leave, while the fomites were swabbed. Swabs for each virus were taken from 120 non-porous surfaces of everyday-use-objects (20 computer keyboards, 24 desktops, 22 computer mice, 24 phones, 18 handles, and 12 light switches) and ten ventilation ducts or air supply diffusers. Numbers of swab samples taken from studied objects were the same in OS and NOS office rooms. The samples were obtained from each surface using a sterile polyester fiber-tipped swabs prewetted in $0.9 \%$ saline solution, which ensures the most effective recovery of viruses from nonporous fomites (Ganime et al. 2015; Julian et al. 2011; Park et al. 2017). After swabbing, the samples were transported to the laboratory vertically in a special container at temperature of $4{ }^{\circ} \mathrm{C}$. RNA isolation was performed within $24 \mathrm{~h}$ from collection of the swabs, which guarantees the highest efficiency of the isolation process.

\section{Viral RNA Extraction}

RNA from swab samples was extracted with Viral Mini Kit PLUS (Syngen, Poland) based on silica column chromatography according to the procedure recommended by the manufacturer. An initial volume of $150 \mu \mathrm{l}$ was used in the RNA extraction process to produce a final volume of $50 \mu$ l. Obtained RNA samples were stored at $-80{ }^{\circ} \mathrm{C}$ until final analyze.

\section{Reverse-Transcription Quantitative PCR for Virus Detection}

One-step reverse transcription quantitative polymerase chain reaction (RT-qPCR) was performed on a CFX96 Real-Time PCR thermocycler (BioRad, USA). Detection of HPIV1, HPIV3, NoV GI, and NoV GII was carried out using commercial kits, i.e., Human Parainfluenza Virus Type 1 (HPIV1) Haemagglutinin-Neuraminidase Glycoprotein, 
Human Parainfluenza Virus Type 3 (HPIV3) Haemagglutinin-Neuraminidase and Norovirus Genogroups 1 and 2Norovirus GI capsid protein gene and Norovirus GII RNA dependent RNA polymerase gene (genesig ${ }^{\circledR}$ PrimerDesign, Ltd., United Kingdom) dedicated to in vitro quantification of virus genomes. According to the manufacturer information, the applied kits were designed to have the possible broadest detection profile whilst remaining specific to the virus genomes. Based on a comprehensive bioinformatics analysis, the primers and probe sequences in these kits have $100 \%$ homology with a broad range of HPIV1, HPIV3, NoV GI, and Nov GII sequences, respectively.

Each reaction mixture $(20 \mu \mathrm{l})$ contained $10 \mu \mathrm{loasig}^{\mathrm{TM}}$ lyophilised OneStep qRT-PCR MasterMix (PrimerDesign, Ltd.), $1 \mu \mathrm{l}$ primer/probe mix, $1 \mu \mathrm{l}$ internal extraction control primer/probe mix, $3 \mu \mathrm{l}$ RNse-free water, and $5 \mu \mathrm{l}$ of RNA sample. Reverse transcription was carried out at $55^{\circ} \mathrm{C}$ for $10 \mathrm{~min}$, followed by denaturation at $95{ }^{\circ} \mathrm{C}$ for $10 \mathrm{~s}$. cDNA was immediately amplified with 49 cycles at $95^{\circ} \mathrm{C}(2 \mathrm{~min})$, $60{ }^{\circ} \mathrm{C}(60 \mathrm{~s})$, and $60{ }^{\circ} \mathrm{C}(60 \mathrm{~s})$. According to the manufacturer's instruction, fluorogenic data were collected during the FAM and VIC channel. Negative and positive controls were included in each run. HPIVs' and NoVs' positive controls were purchased from PrimerDesign Ltd.

To minimize the potential contamination, all analytical steps including: RNA isolation, reagent preparation, sample preparation, and amplification were carried out in separate rooms. In all performed analyses, the sterile filter pipette tips free from RNase and DNase were only used.

RT-qPCR data were collected after the reaction and the threshold values defined the quantification cycle $(\mathrm{Cq})$ were calculated by the BioRad CFX96 Manager Software. Samples with $\mathrm{Cq} \leq 40$ and with $25 \leq \mathrm{Cq} \leq 31$ for internal extraction control were considered as positive according to manufacturer's instruction. Samples negative or with $\mathrm{Cq}>40$ were retested after 10-fold dilution, which allowed to evaluate possible presence of inhibitors (Fusco et al. 2017).

Quantification analysis was carried out with standard curves, constructed by amplification of tenfold dilutions of the positive control (standard from 1 to $1 \times 10^{6}$ copies/ reaction). Log RNA copies were plotted against $\mathrm{Cq}$ value. For each standard curve, amplification efficiency $(E)$ was calculated as described by Fusco et al. (2017). The results expressed as the number of RNA copies per $100 \mathrm{~cm}^{2}$ of tested surfaces (copies $/ 100 \mathrm{~cm}^{2}$ ) were calculated taking into account the volumes of solutions used for extraction and RNA isolation according to the following formula:

$N_{100 \mathrm{~cm}^{2}}=\left[\left(N_{0} \times V_{2} / V_{1}\right) / A\right] \times 100$,

where $N_{100 \mathrm{~cm}^{2}}$ number of RNA copies per $100 \mathrm{~cm}^{2}, N_{0}-$ starting quantity or RNA copies, $V_{2}$-volume of solution used for extraction $(\mu \mathrm{l}), V_{1}$-volume of sample taken for isolation $(\mu \mathrm{l}), A$-tested surface $\left(\mathrm{cm}^{2}\right)$.

\section{Statistical Analysis}

Statistical analyses were carried out with Kruskal-Wallis, Mann-Whitney U, $\chi^{2}$, and Fisher Exact tests using STATISTICA, version 7.1 (StatSoft, USA). $p$ values below 0.05 were considered statistically significant.

\section{Results}

\section{Virus Detection by RT-qPCR}

RT-qPCR-based studies showed the presence of HPIVs and NoVs on the examined surfaces. Overall, $20.8 \%$ of the samples were positive. Among positive samples, $59.3 \%$ of them were HPIV3-positive, 25.9\% HPIV1-positive, and 14.8\% NoV GII-positive. NoV GI was not detected on examined surfaces. The most commonly detected virus was HPIV3, followed by HPIV1 and NoV GII. HPIV3 dominated on office equipment objects such as computer keyboards (20\% of the tested samples were positive), computer mice (18\%), telephones (17\%), and desktops (17\%). HPIV1 was the most commonly detected on computer mice (9\%), telephones (8\%), and desktops (8\%). In contrast to the HPIV3, HPIV1 was reported less frequently on the surfaces of computer keyboards (5\%). NoV GII was detected on the light switches (17\%) and door handles (11\%). There was no viral RNA detected in the swab samples collected from ventilation system (Table 1).

Taking into account the occurrence of co-contamination of tested surfaces, viral RNA of HPIV1 and HPIV3 were detected in the same time in case of two telephones, one computer keyboard, one computer mouse, and one desktop. Co-contaminated surfaces represent $3.8 \%$ of the total tested samples. There were no samples contaminated with NoV and HPIV in the same time.

Statistical analysis showed that the surfaces of office equipment (computer keyboards and mice, telephones, desktops) were significantly more contaminated with HPIVs than the surfaces of building components (door handles, light switches, ventilation system) $\left(\chi^{2} p=0.006\right.$; Fisher Exact test $p=0.004)$. All examined surfaces were significantly more contaminated with HPIVs than with NoVs $\left(\chi^{2}\right.$ test $p=0.002$; Fisher Exact test $p=0.003$ ).

Majority of HPIVs-positive samples came from OS rooms (74\%), whereas NoVs-positive samples from NOS rooms (75\%) (Table 2); however statistical analysis confirmed such prevalence of contamination for HPIVs only $\left(\chi^{2}\right.$ test $p=0.016$; Fisher Exact test $p=0.013$ ). The quantity of HPIVs-positive surfaces amongst the studied object categories varied between 66.7 and $83.3 \%$ and between 16.7 and $33.3 \%$ for OS and NOS rooms, respectively. In OS rooms, HPIVs were most often detected on computer mice (83.3\%), 
Table 1 Number and percentage of virus-positive swab samples as identified by RT-qPCR

\begin{tabular}{|c|c|c|c|c|c|c|c|c|}
\hline \multirow[t]{2}{*}{ Virus detected } & \multicolumn{7}{|c|}{ Number and percentage of positive samples (\%) } & \multirow{2}{*}{$\begin{array}{l}\text { Total numbe } \\
\text { of analyzed } \\
\text { samples }\end{array}$} \\
\hline & Computer keyboard & Computer mouse & Telephone & Desktop & Door handle & Light switch & $\begin{array}{l}\text { Ventila- } \\
\text { tion } \\
\text { system }\end{array}$ & \\
\hline HPIV1 & $1 / 20(5)$ & $2 / 22(9)$ & $2 / 24(8)$ & $2 / 24(8)$ & N.D. & N.D. & N.D. & $7 / 130(5)$ \\
\hline HPIV3 & $4 / 20(20)$ & $4 / 22(18)$ & $4 / 24(17)$ & $4 / 24(17)$ & N.D. & N.D. & N.D. & 16/130 (12) \\
\hline NoV GI & N.D. & N.D. & N.D. & N.D. & N.D. & N.D. & N.D. & N.D. \\
\hline NoV GII & N.D. & N.D. & N.D. & N.D. & $2 / 18$ & 2/12 (17) & N.D. & 4/130 (3) \\
\hline
\end{tabular}

N.D not detected

Table 2 Percentage of HPIVand NoV-positive samples on fomites in open-space (OS) and non-open-space (NOS) rooms

\begin{tabular}{|c|c|c|c|c|c|}
\hline \multirow[t]{4}{*}{ Surface } & \multirow{4}{*}{$\begin{array}{l}\text { Total number of posi- } \\
\text { tive samples }\end{array}$} & \multicolumn{4}{|c|}{ Percentage of positive samples (\%) } \\
\hline & & \multicolumn{4}{|l|}{ Virus } \\
\hline & & \multicolumn{2}{|c|}{ HPIVs (HPIV1, HPIV3) } & \multicolumn{2}{|l|}{ NoV GII } \\
\hline & & OS & NOS & OS & NOS \\
\hline Keyboard & 5 & $4 / 5(80.0)$ & $1 / 5(20.0)$ & N.D. & N.D. \\
\hline Computer mouse & 6 & $5 / 6(83.3)$ & $1 / 6(16.7)$ & N.D. & N.D. \\
\hline Telephone & 6 & $4 / 6(66.7)$ & $2 / 6(33.3)$ & N.D. & N.D. \\
\hline Desktop & 6 & $4 / 6(66.7)$ & 2/6 (33.3) & N.D. & N.D. \\
\hline Door handle & 2 & N.D. & N.D. & $1 / 2(50)$ & $1 / 2(50)$ \\
\hline Light switch & 2 & N.D. & N.D. & N.D. & $2 / 2(100)$ \\
\hline Total & 27 & 74 & 26 & 25 & 75 \\
\hline
\end{tabular}

N.D. not detected while in NOS rooms on telephones and desktops (in both cases: $33.3 \%$ ). In OS rooms, NoVs were only detected on door handles. Enteric viruses on light switches were found only in NOS rooms; however, all these samples (100\%) were contaminated with them.

\section{Standard Curves and Virus Quantification}

For each virus, a standard curve was plotted based on the average $\mathrm{Cq}$ values of three replicates against the amount of copies/reaction. The efficiencies of amplification $\left(E=10^{-1 /}\right.$ $\mathrm{S}_{-}$, where $S$ is the slope of linear regression curve) for each standard curve were as follows: $E_{\mathrm{HPIV} 1}=1.05(S=-3.20$, $\left.r^{2}=0.98\right), E_{\mathrm{HPIV} 3}=0.95\left(S=-3.45, r^{2}=0.99\right)$, $E_{\mathrm{NoV} \mathrm{GI}}=0.97\left(S=-3.56, r^{2}=0.98\right)$, and $E_{\mathrm{NoV} \mathrm{GII}}=1.04$ $\left(S=-3.24, r^{2}=0.99\right)$. The estimated detection level for tested viruses was 10 copies/reaction.

The mean quantities for tested viruses ranged between $10^{1}$ and $10^{3}$ RNA copies $/ 100 \mathrm{~cm}^{2}$ (Table 3 ). The highest concentration of HPIV RNA copies was observed on telephones (average $1.66 \times 10^{3}$ copies $/ 100 \mathrm{~cm}^{2}$, range $4.89 \times 10^{2}$ to $2.63 \times 10^{3}$ copies $/ 100 \mathrm{~cm}^{2}$ ). The average concentration of HPIV RNA copies on other surfaces were $3.36 \times 10^{2}$, $4.85 \times 10^{2}$, and $5.90 \times 10^{1}$ copies $/ 100 \mathrm{~cm}^{2}$ for computer
Table 3 Average concentrations of HPIVs and NoVs RNA copies/100 $\mathrm{cm}^{2}$ in positive swab samples (mean values and standard deviations, $\mathrm{SD}$ ) regarding to object category

\begin{tabular}{|c|c|c|c|c|}
\hline \multirow[t]{3}{*}{ Surface } & \multicolumn{4}{|l|}{ Virus } \\
\hline & \multicolumn{2}{|c|}{ HPIVs (HPIV1, HPIV3) } & \multicolumn{2}{|l|}{ NoV GII } \\
\hline & Mean value & SD & Mean value & SD \\
\hline Keyboard & $3.36 \times 10^{2}$ & $2.37 \times 10^{2}$ & N.D. & N.D. \\
\hline Computer mouse & $5.90 \times 10^{1}$ & $2.20 \times 10^{1}$ & N.D. & N.D. \\
\hline Telephone & $1.66 \times 10^{3}$ & $1.09 \times 10^{3}$ & N.D. & N.D. \\
\hline Desktop & $4.85 \times 10^{2}$ & $4.65 \times 10^{2}$ & N.D. & N.D. \\
\hline Door handle & N.D. & N.D. & $5.06 \times 10^{1}$ & $3.97 \times 10^{1}$ \\
\hline Light switch & N.D. & N.D. & $1.40 \times 10^{2}$ & $8.09 \times 10^{1}$ \\
\hline
\end{tabular}

N.D. not detected

keyboards, desktops, and computer mice, respectively. The highest concentration of NoV RNA copies was observed on light switches (average: $1.40 \times 10^{2}$ copies $/ 100 \mathrm{~cm}^{2}$, range: $1.10-1.70 \times 10^{2}$ copies $/ 100 \mathrm{~cm}^{2}$ ). The concentration of NoV RNA copies on door handles was detected at level of $5.06 \times 10^{1}$ copies $/ 100 \mathrm{~cm}^{2}$. However, the Kruskal-Wallis test did not show statistically significant differences in concentrations of RNA copies between the tested surfaces. 
The average concentration of HPIV RNA copies was higher on surfaces located in OS rooms than in NOS ones $\left(8.20 \times 10^{2}\right.$ vs. $2.89 \times 10^{2}$ RNA copies $\left./ 100 \mathrm{~cm}^{2}\right)$ (Table 4$)$. In case of NoV RNA copies, the opposite relation was observed $\left(5.61 \times 10^{1}\right.$ vs. $8.70 \times 10^{1}$ RNA copies $\left./ 100 \mathrm{~cm}^{2}\right)$; however, in both cases, the observed differences were not statistically significant (Mann-Whitney $U$ test: $p>0.05$ ).

\section{Discussion}

There have been many studies examining the presence of bacteria and fungi on indoor fomites, but there is still lack of knowledge about viral nucleic acids, which can be found on everyday-use objects. Our study is the first investigation qualitatively and quantitatively analyzing presence of the most common respiratory and enteric viruses on everydayuse objects in the offices. Viral RNA of HPIVs and NoVs was detected on both office equipment (computer keyboards and mice, telephones, desktops) and building elements (door handles, light switches). This fact reinforces the theory that viruses can be easily spread within indoor environments (Goldman 2000). Viruses are probably the most common cause of infections spreading in buildings with large concentration of people (Brady et al. 1990). Many studies have documented the possibility of transferring the viruses from hands to the surfaces of touched objects and back, which may play an important role in spreading of viral infections (Ansari et al. 1988, 1991; Julian et al. 2010; Zhao et al. 2005).

In the current study, we found that both HPIV1 and HPIV3 viruses may be present on computer keyboards, mice, telephones, and desktops. It is consistent with Boone and Gerba (2010) observations describing the prevalence of HPIV1 on office equipment. However, in opposite to these authors, we did not find these viruses on door handles and light switches. The majority of HPIV-positive samples collected from office equipment seem to result from the transfer of contaminated nasal and respiratory secretions to fomites by touching (hand-nose/mouth-surface) and during coughing, sneezing, and talking. According to Couch et al. (1974),

Table 4 Average concentrations of HPIVs and NoVs RNA copies/100 $\mathrm{cm}^{2}$ in positive swab samples (mean values and standard deviations, SD) regarding to the type of room

\begin{tabular}{|c|c|c|c|c|}
\hline \multirow[t]{3}{*}{ Room } & \multicolumn{4}{|l|}{ Virus } \\
\hline & \multicolumn{2}{|c|}{ HPIVs (HPIV1, HPIV3) } & \multicolumn{2}{|l|}{ NoV GII } \\
\hline & Mean value & SD & Mean value & SD \\
\hline OS & $8.20 \times 10^{2}$ & $9.47 \times 10^{2}$ & $5.61 \times 10^{1}$ & $2.83 \times 10^{0}$ \\
\hline NOS & $2.89 \times 10^{2}$ & $1.63 \times 10^{2}$ & $8.70 \times 10^{1}$ & $5.13 \times 10^{1}$ \\
\hline
\end{tabular}

OS open-space rooms, NOS non-open-space rooms up to $10^{7}$ infectious virions can be present in $1 \mathrm{ml}$ of respiratory secretions. When sneezing, they can travel up to $3 \mathrm{~m}$ at a speed of $20 \mathrm{~m} / \mathrm{s}$ contaminating surrounding surfaces (Zhao et al. 2005).

NoVs were found only on door handles and light switches. These results confirmed the possibility of enteric virus occurrence on frequently touched objects, as described by Cheesbrough et al. (2000). Noroviruses may be numerously present in the saliva of infected individuals, but the highest concentrations of virions are observed in the feces and vomits (Atmar et al. 2008). The presence of NoVs on frequently touched surfaces suggests that they were transferred by contaminated hands. As indicated by Barker et al. (2004), NoVs virions present on the fingers may contaminate up to seven consecutive surfaces. These viruses can easily attach to stainless steel (e.g., door handles) or plastic (e.g., light switches) surfaces and survive on them from 4 to almost 6 days (Girard et al. 2010; Kim et al. 2014). In the case of enteric virus infection, a single vomiting incident can cause the release up to 30 million viral particles in the form of bioaerosol. As it was also showed, the virions released during the toilet flushing may survive in the air long enough to contaminate the surfaces of objects in immediate surroundings (Ansari et al. 1988; Zhao et al. 2005). Hence, it is worth mentioning that viral particles emissions to the environment can occur not only during illness but also before the symptoms appear as well as for a few days or weeks after the disease has ended (Goldman 2000). In case, when hygiene level is insufficient, a transfer of the virus from hands to the touched surfaces is very possible.

In the present study, swab samples from non-porous surfaces were analyzed. According to Abad et al. (1994), viruses usually survive for longer time on non-porous surfaces compared to porous ones. The stability of viruses on surfaces may vary and depend on several factors. In indoor environments, both UV radiation and $\mathrm{pH}$ of the surfaces have a limited influence, whereas temperature and relative humidity can play an important role in viral genome stability; however, simultaneous impact of these factors is difficult to assess (Memarzadeh 2012). According to Choi et al. (2014), viral single-stranded RNA is less resistant to degradation by high temperature than double-stranded DNA.

Viral genome stability and infection ability may increase or decrease depending on the number of microbes present on the surfaces (Boone and Gerba 2007). Bacteria and fungi may exhibit protective effects against virions (securing against drying and disinfection). On the other hand, the effects of bacterial proteases and fungal enzymes can adversely influence the environmental stability of viruses (Boone and Gerba 2007; Sobsey and Meschke 2003).

Considering viral infectious capacity, specific infectious dose is difficult to determine. According to the Infectious Disease Epidemiology Section at the Department of 
Health and Hospitals in Louisiana, NoVs infectious dose is estimated as 10 viral particles introduced into the body per os (Louisiana Office of Public Health 2013). Other data indicate that less than 10 virions are sufficient to infect a healthy adult (Hutson et al. 2004). Similar information is provided by the Public Health Agency of Canada (PHAC). Hall (2012) determined the norovirus infectious dose at the level of $\geq 18$ viral particles. In turn, animal studies show that infectious per os dose of human NoVs GII for gnotobiotic pigs range from $10^{3}$ to $10^{4}$ viral RNA copies (Bui et al. 2013). According to PHAC, HPIVs infectious dose is unknown; however, some authors indicate that for HPIV1, $\geq 1.5$ units of virus is enough to induce infection when viruses are introduced into the body through the nasal drops (Collins and Kennedy 1999). Taking into account all these information, the results obtained in the current study from office buildings showed that viruses present on tested surfaces may play important role in infections of occupants, especially in situation when personal hygiene is insufficient (e.g., when there are no hand washing before leaving the toilet, using single-use handkerchiefs, hand washing after sneezing or coughing etc.). On the other hand, it should be clearly stated that the positive samples obtained in this study may contain both infectious and non-infectious viral particles as detected with RT-q PCR method. Although one-step RT-qPCR enables both qualitative and quantitative analyses of viral RNA, this method does not allow assessing viral infectious ability (Rodríguez et al. 2009). A big step forward in the determination of viral infectivity is the viability PCR (vPCR). In this method, through the use of a simple sample pre-treatment with specific intercalating reagents (e.g., viability dyes like propidium monoazide or ethidium monoazide), it is possible to distinguish viral RNA from non-intact viral particles (Topping et al. 2009). On the other hand, an attempt to use viability dyes for the detection of infectious noro- or influenza viruses with RT-qPCR was not so far successful (Parshionikar et al. 2010; Graiver et al. 2010; Elizaquível et al. 2013). Hence, the assessment of infectivity of the viruses transferred from fomites to humans needs further investigations.

The surfaces of office objects like telephones, computer keyboards, mice or desktops, as well as door handles and light switches are frequently used but rarely cleaned and disinfected. HPIVs can be efficiently removed from the surfaces with a majority of commonly used detergents, disinfectants or antiseptic agents (Brady et al. 1990). However in case of NoVs, the outbreak investigations indicated that enteric viruses are relatively resistant to common disinfectants (Cheesbrough et al. 2000; D'Souza et al. 2006). According to Girard et al. (2010), only sodium hypochlorite was sufficiently effective against NoVs, while alcohols and ammonium-based disinfectants were less efficient.
Based on this study, it can be concluded that individuals in office environment may have contact with viral RNA present on different frequently touched surfaces. Keeping the personal hygiene on a proper level as well as regular and effective cleaning of the surfaces (including desktops, computer keyboards and mice, telephones, handles, light switches etc.) with proper disinfectants degrading viral RNA should reduce the possibility of virus transmission and infections among occupants.

Funding This project has been based on the results of a research task carried out within the scope of the statutory activity (I-49/TSB) of the Central Institute for Labour Protection-National Research Institute in 2016-2017 supported by the Ministry of Science and Higher Education.

\section{Compliance with Ethical Standards}

Conflict of interest The authors declare that they have no conflict of interest.

Open Access This article is distributed under the terms of the Creative Commons Attribution 4.0 International License (http://creativecommons.org/licenses/by/4.0/), which permits unrestricted use, distribution, and reproduction in any medium, provided you give appropriate credit to the original author(s) and the source, provide a link to the Creative Commons license, and indicate if changes were made.

\section{References}

Abad, F. X., Pinto, R. M., \& Bosch, A. (1994). Survival of enteric viruses on environmental fomites. Applied and Environmental Microbiology, 60, 3704-3710.

Aitken, C., \& Jefferies, D. J. (2001). Nosocomial spread of viral disease. Clinical Microbiology Reviews, 14, 528-546.

Ansari, S. A., Sattar, S. A., Springthrope, G. A., Wells, G. A., \& Tostowaryk, W. (1988). Rotavirus survival on human hands and transfer of infectious virus to animate and non-porous inanimate surfaces. Journal of Clinical Microbiology, 26, 1513-1518.

Ansari, S. A., Springthrope, V. S., Sattar, S. A., Rivard, S., \& Rahman, M. (1991). Potential role of hands in the spread of respiratory viral infections: Studies with human Parainfluenza virus 3 and Rhinovirus 14. Journal of Clinical Microbiology, 29, 2115-2119.

Arias, C., Sala, M. R., Dominguez, A., Torner, N., Ruiz, L., Martinez, A., et al. (2009). Epidemiological and clinical features of norovirus gastroenteritis in outbreaks: A population-based study. Clinical Microbiology and Infection, 16, 39-44.

Atmar, R. L., Opekun, A. R., Gilger, M. A., Estes, M. K., Crawford, S. E., Neill, F. H., et al. (2008). Norwalk virus shedding after experimental human infection. Emerging Infectious Diseases, 14(10), 1553-1557.

Barker, J., Stevens, D., \& Bloomfield, S. F. (2001). Spread and prevention of some common viral infections in community facilities and domestic homes. Journal of Applied Microbiology, 91, 7-21.

Barker, J., Vipond, I. B., \& Bloomfield, S. F. (2004). Effects of cleaning and disinfection in reducing the spread of norovirus contamination via environmental surfaces. Journal of Hospital Infection, $58,42-44$ 
Boone, S. A., \& Gerba, C. P. (2007). Significance of fomites in the spread of respiratory and enteric viral diseases. Applied and Environmental Microbiology, 73(6), 1687-1696.

Boone, S. A., \& Gerba, C. P. (2010). The prevalence of human parainfluenza virus 1 on indoor office fomites. Food and Environmental Virology, 2(1), 41-46.

Brady, M. T., Evans, J., \& Cuartas, J. (1990). Survival and disinfection of parainfluenza viruses on environmental surfaces. American Journal of Infection Control, 8, 18-23.

Bui, T., Kocher, J., Li, Y., Wen, K., Li, G., Liu, F., et al. (2013). Median infectious dose of human norovirus GII.4 in gnotobiotic pigs is decreased by simvastatin treatment and increased by age. Journal of General Virology, 94, 2005-2016.

Cheesbrough, J. S., Green, J., Gallimore, C. I., Wright, P. A., \& Brown, D. W. (2000). Widespread environmental contamination with Norwalk-like viruses (NLV) detected in a prolonged hotel outbreak of gastroenteritis. Epidemiology and Infection, 125, 93-98.

Choi, W. S., Rodríguez, R. A., \& Sobsey, M. D. (2014). Persistence of viral genomes after autoclaving. Journal of Virological Methods, 198, 37-40.

Collins, P. L., Chanock, R. M., \& McIntosh, K. (1996). Parainfluenza viruses. In B. N. Fields, D. M. Knipe, \& P. M. Howley (Eds.), Virology (3rd ed., pp. 1205-1241). Philadelphia: LippincottRaven Publications.

Collins, C. H., \& Kennedy, D. A. (1999). Exposure, sources and route of infection. Laboratory-acquired Infection: History, incidence, causes and preventions (pp. 38-53). Oxford: Butterworth-Heinemann.

Couch, R. B., Kasel, J. A., Gerin, J. L., Schulman, J. L., \& Kibourne, E. D. (1974). Induction of partial immunity to influenza by a neuraminidase-specific vaccine. Journal of Infectious Diseases, 129, 411-420.

D’Souza, D. H., Sair, A., Williams, K., Papafragkou, E., Jean, J., Moore, C., et al. (2006). Persistence of calcivirus on environmental surfaces and their transfer to food. International Journal of Food Microbiology, 108, 84-91.

Doultree, J. C., Druce, J. D., Birch, C. J., Bowden, D. S., \& Marshall, J. A. (1999). Inactivation of feline calicivirus, a Norwalk virus surrogate. Journal of Hospital Infection, 41(1), 51-57.

Elizaquível, P., Aznar, R., \& Sánchez, G. (2013). Recent developments in the use of viability dyes and quantitative PCR in the food microbiology field. Journal of Applied Microbiology, 116, 1-13.

Estes, M. K., Verkataram, B. V., \& Atmar, R. L. (2006). Noroviruses everywhere: Has something changed? Current Opinion in Infectious Diseases, 19, 467-474.

Falsey, A. R., Cunningham, C. K., Barker, W. H., Kouides, R. W., Yuen, J. B., Menegus, M., et al. (1995). Respiratory syncytial virus and influenza A infections in the hospitalized elderly. Journal of Infectious Diseases, 172, 389-394.

Fusco, G., Di Bartolo, I., Cioffi, B., Ianiro, G., Palermo, P., Monini, M., et al. (2017). Prevalence of foodborne viruses in mussels in Southern Italy. Food and Environmental Virology, 9, 187-194.

Ganime, A. C., Leite, J. P. G., de Abreu Corrêa, A., Melgaço, F. G., \& Carvalho-Costa, F. A. (2015). Evaluation of the swab sampling method to recover viruses from fomites. Jorunal of Virological Methods, 217, 24-27.

Gerba, C.P., (2014). Impact of a Quaternary Ammonium Compound (QAC) Disinfectant on the spread of viruses in facilities, In: Proceedings of the 54th Interscience Conference on Antimicrobial Agents and Chemotherapy (ICAAC), Washington, 5-9th September, 2014.

Girard, M., Ngazoa, S., Mattison, K., \& Jean, J. (2010). Attachment of noroviruses to stainless steel and their inactivation, using household disinfectants. Journal of Food Protection, 73(2), 400-404.
Glasgow, K. W., Tamblyn, S. E., \& Blair, G. (1995). A respiratory outbreak due to parainfluenza virus type 3 in a home for the agedOntario. Canada Communicable Disease Report, 21, 57-61.

Glezen, W. P., Frank, A. L., Taber, L. H., \& Kasel, J. A. (1984). Parainfluenza virus type 3: Seasonality and risk of infection and reinfection in young children. Journal of Infectious Diseases, 150, 851-857.

Glezen, W. P., Greenberg, S. B., Atmar, R. L., Piedra, P. A., \& Cough, R. B. (2000). Impact of respiratory virus infections on persons with chronic underlying conditions. Journal of the American Medical Association, 283, 499-505.

Goldman, D. A. (2000). Transmission of viral respiratory infections in the home. Pediatric Infectious Disease Journal, 19, 97-102.

Graiver, D. A., Saunders, S. E., Topliff, C. L., Kelling, C. L., \& Bartelt-Hunt, S. L. (2010). Ethidium monoazide does not inhibit RT-PCR amplification of nonviable avian influenza RNA. Journal of Virological Methods, 164, 51-54.

Green, K. (2013). Caliciviridae the noroviruses. In D. M. Knipe, P. M. Howley, J. I. Cohen, D. E. Griffin, R. A. Lamb, \& M. A. Martin (Eds.), Fields Virology (6th ed., pp. 583-609). Philadelphia: Lippincott Williams.

Hall, A. J. (2012). Noroviruses: The perfect human pathogens? Journal of Infectious Diseases, 205(11), 1622-1624.

Hall, A. J., Lopman, B. A., \& Payne, D. C. (2013). Norovirus disease in the United States. Emerging Infectious Diseases, 19, 1198-1205.

Hall, A. J., Vinjé, J., Lopman, B., Park, G. W., Yen, C., et al. (2011). Updated norovirus outbreak management and disease prevention guidelines. Recommendations and Reports, 4(60), 1-15.

Hendley, J. O. (1990). Parainfluenza viruses. In G. L. Mandel, R. G. Douglas, \& J. E. Bennett (Eds.), Principles and practice of infectious diseases (3rd ed., pp. 1255-1260). New York: Churchill Livingstone.

Hendrickson, K. J. (2003). Parainfluenza viruses. Clinical Microbiology Reviews, 16, 2242-2264.

Huhti, L., Szakal, E. D., Puustinen, L., Salminen, M., Huhtala, H., Valve, O., et al. (2011). Norovirus GII-4 causes a more severe gastroenteritis than other noroviruses in young children. The Journal of Infectious Diseases, 203, 1442-1444.

Hutson, A. M., Atmar, R. L., \& Estes, M. K. (2004). Norovirus diseases: Changing, epidemiology and host susceptibility factors. Trends in Microbiology, 12(6), 279-287.

Jarvis, W. R., Middletonm, P. J., \& Gelfand, E. W. (1979). Parainfluenza pneumonia in severe combined immunodeficiency disease. Journal of Pediatrics, 94, 423-425.

Julian, T. R., Leckie, J. O., \& Boehm, A. B. (2010). Virus transfer between fingerpads and fomites. Journal of Applied Microbiology, 109, 1868-1874.

Julian, T. R., Tamayo, F. J., Leckie, J. O., \& Boehm, A. B. (2011). Comparison of surface sampling methods for virus recovery from fomites. Applied and Environmental Microbiology, 77(19), 6918-6925.

Kim, A. N., Park, S. Y., Bae, S. C., Oh, M. H., \& Ha, S. D. (2014). Survival of norovirus surrogate on various food-contact surfaces. Food and Environmental Virology, 6, 182-188.

Koopmans, M., \& Duizer, E. (2004). Foodborne viruses: An emerging problem. International Journal of Food Microbiology, 90, 23-41.

La Rosa, G., Fratini, M., Della Libera, S., Iaconelli, M., \& Muscillo, M. (2013). Viral infections acquired indoors through airborne, droplet or contact transmission. Annali dell'Istituto Superiore di Sanità, 49(2), 124-132.

Liu, W. K., Liu, Q., Chen, D. H., Liang, H. X., Chen, X. K., Huang, W. B., et al. (2013). Epidemiology and clinical presentation of the four human parainfluenza virus types. BMC Infectious Diseases, 13, 28. 
Louisiana Office of Public Health-Infectious Disease Epidemiology Section, Norovirus Infections, 2013, 2-3, http://new.dhh.louisiana. gov/assets/oph/Center-PHCH/Center-CH/infectious-epi/EpiManual/NorovirusManual.pdf.

Marshall, J. A., Dimitridas, A., \& Wright, P. J. (2005). Molecular and epidemiological features of norovirus-associated gastroenteritis outbreaks in Victoria, Australia in 2001. Journal of Medical Virology, 75, 321-331.

McElhaney, J. (2003). Epidemiology in elderly people. Influenza Info News, 16, 3.

Memarzadeh, F. (2012). Literature review of the effect of temperature and humidity on viruses. ASHRAE Transactions, 118(1), 1049-1060.

Park, G. W., Chhabra, P., \& Vinje, J. (2017). Swab sampling method for the detection of human norovirus on surfaces. Journal of Visualized Experiments, 120, e55205.

Parshionikar, S., Laseke, I., \& Fout, G. S. (2010). Use of propidium monoazide in reverse transriptase PCR to distinguish between infectious and noninfectious enteric viruses in water samples. Applied and Environmental Microbiology, 76, 4318-4326.

Pruss-Ustun, A., Covalan, C., (2006), Almost a quarter of all disease caused by environmental exposure, WHO, Geneva, Switzerland, http://www.phac-aspc.gc.ca/msds-ftss/.

Rodríguez, R., Pepper, I. L., \& Gerba, C. P. (2009). Application of PCR-based methods to assess the infectivity of enteric viruses in environmental samples. Applied and Environmental Microbiology, 75(2), 297-307.

Sobsey, M.D., Meschke, J.S., (2003). Virus survival in the environment with special attention to survival in sewage droplets and other environmental media of fecal or respiratory origin, http://www. iapmo.org/common/pdf/ISS-Rome/Sobsey_Environ_Report.pdf.
Topping, J. R., Schnerr, H., Haines, J., Scott, M., Carter, M. J., Willcocks, M. M., et al. (2009). Temperature inactivation of feline calcivirus vaccine strain FCV F-9 in comparison with human noroviruses using an RNA exposure assay and reverse transcribed quantitative realtime polymerase chain reaction: A novel method for predicting virus infectivity. Journal of Virological Methods, 156, 89-95.

Tuladhar, E., Hazeleger, W. C., Koopmans, M., Zwietering, M. H., Beumer, R. R., \& Duizer, E. (2012). Residual viral and bacterial contamination of surfaces after cleaning and disinfection. Applied and Environmental Microbiology, 78(21), 7769-7775.

Vinjé, J. (2015). Advances in laboratory methods for detection and typing of norovirus. Journal of Clinical Microbiology, 53(2), 373-381.

von Rheinbaben, F., Schunemann, S., Gross, T., \& Wolff, M. H. (2000). Transmission of viruses via contact in a household setting: experiments using bacteriophage strain phiXI174 as a model virus. Journal of Hospital Infection, 46, 61-66.

Wendt, C. H., Weisdorf, D. J., Jordan, M. C., Balfour, H. H., \& Hertz, M. I. (1992). Parainfluenza virus respiratory infection after bone marrow transplantation. New England Journal of Medicine, 326, 921-926.

Whimbey, E., Englund, J. A., \& Ljungman, P. (1997). Community respiratory viral infections in the immunocompromised patients with cancer. American Journal of Medicine, 102(3), 10-18.

Zhao, B., Zhao, Z., \& Xianing, L. (2005). Numerical study of the transport of droplets or particles by respiratory systems indoors. Building and Environment, 4, 1032-1039. 